\title{
Pre-Late Wisconsinan age for part of the glaciolacustrine stratigraphy, lower Peabody valley, northern White Mountains, Gorham, New Hampshire
}

La stratigraphie glaciolacustre partiellement du pré-Wisconsinien supérieur de la vallée inférieure du Peabody, White Mountains septentrionales (Gorham, New Hampshire, É.-U.A.)

\section{Prä-Spät-Wisconsin-Alter für einen Teil der glazialen Seen-Stratigraphie im unteren Teil des Peabody-Tals, nördliche White Mountains, Gorham, New Hampshire}

\author{
Brian K. Fowler
}

Volume 53, numéro 1, 1999

Late Quaternary History of the White Mountains, New Hampshire and Adjacent Southeastern Québec

URI : https://id.erudit.org/iderudit/004817ar

DOI : https://doi.org/10.7202/004817ar

Aller au sommaire du numéro

Éditeur(s)

Les Presses de l'Université de Montréal

ISSN

0705-7199 (imprimé)

1492-143X (numérique)

Découvrir la revue

Citer cet article

Fowler, B. K. (1999). Pre-Late Wisconsinan age for part of the glaciolacustrine stratigraphy, lower Peabody valley, northern White Mountains, Gorham, New Hampshire. Géographie physique et Quaternaire, 53(1), 109-116.

https://doi.org/10.7202/004817ar
Résumé de l'article

Le till interstratifié et les dépôts glaciolacustres de la vallée du cours inférieur du Peabody laissent penser que les avancées glaciaires ont été nombreuses dans la région. Les chercheurs ont supposé que ces avancées étaient soit locales, soit régionales, mais tous ont cru qu'elles dataient des stades de retrait de l'inlandsis du Wisconsinien supérieur. Toutefois, de nouvelles recherches ont permis de découvrir qu'un till épais et de grande étendue domine la stratigraphie et qu'il a été mis en place au pléniglaciaire du Wisconsinien supérieur. La position stratigraphique de ce till indique donc que le till sous-jacent et les dépôts glaciolacustres sont antérieurs au Wisconsinien supérieur et passablement plus anciens que ce que l'on croyait jusqu'à maintenant. Un tel changement dans l'âge d'une partie de la stratigraphie de la vallée du Peabody permet d'étendre l'existence de la stratigraphie « à deux tills » de l'Illinoien-Wisconsinien supérieur du centre et du sud de la Nouvelle-Angleterre jusqu'au nord des hautes terres des White Mountains. 


\section{PRE-LATE WISCONSINAN AGE FOR PART OF THE GLACIOLACUSTRINE STRATIGRAPHY, LOWER PEABODY VALLEY, NORTHERN WHITE MOUNTAINS, GORHAM, NEW HAMPSHIRE}

Brian K. FOWLER*, Mount Washington Observatory, c/o North American Reserve, 67 Water Street, Suite 207, Laconia, New Hampshire 03246-3300 U.S.A.

\begin{abstract}
Interbedded till and glaciolacustrine deposits in the lower Peabody River Valley near Gorham, New Hampshire suggest multiple glacial advances occurred in the northern White Mountains. Previous workers disagreed on whether these advances were local or regional in nature, but thought they all occurred during the recessional phase of the Late Wisconsinan ice sheet. New stratigraphic and geomorphic reconnaissance, however, shows that a thick and regionally extensive till overlies this stratigraphy and that this till was emplaced by the last full-glacial episode to affect the region, the Late Wisconsinan glaciation. The stratigraphic position of this till makes the age of the underlying till and glaciolacustrine deposits pre-Late Wisconsinan and much older than previously assumed. This change in age assignment for part of the Peabody Valley stratigraphy supports the extension of the Illinoian-Late Wisconsinan "two-till" stratigraphy of central and southern New England into the region north of the White Mountain Highlands.
\end{abstract}

RÉSUMÉ La stratigraphie glaciolacustre partiellement du pré-Wisconsinien supérieur de la vallée inférieure du Peabody, White Mountains septentrionales (Gorham, New Hampshire, É.-U.A.). Le till interstratifié et les dépôts glaciolacustres de la vallée du cours inférieur du Peabody laissent penser que les avancées glaciaires ont été nombreuses dans la région. Les chercheurs ont supposé que ces avancées étaient soit locales, soit régionales, mais tous ont cru qu'elles dataient des stades de retrait de l'inlandsis du Wisconsinien supérieur. Toutefois, de nouvelles recherches ont permis de découvrir qu'un till épais et de grande étendue domine la stratigraphie et qu'il a été mis en place au pléniglaciaire du Wisconsinien supérieur. La position stratigraphique de ce till indique donc que le till sous-jacent et les dépôts glaciolacustres sont antérieurs au Wisconsinien supérieur et passablement plus anciens que ce que l'on croyait jusqu'à maintenant. Un tel changement dans l'âge d'une partie de la stratigraphie de la vallée du Peabody permet d'étendre l'existence de la stratigraphie « à deux tills » de l'lllinoien-Wisconsinien supérieur du centre et du sud de la Nouvelle-Angleterre jusqu'au nord des hautes terres des White Mountains
ZUSAMMENFASSUNG Prä-Spät-Wisconsin-Alter für einen Teil der glazialen Seen-Stratigraphie im unteren Teil des Peabody-Tals, nördliche White Mountains, Gorham, New Hampshire. Eingebettetes Till und glaziale Seensedimente im unteren Teil des Peabody-Flusstals bei Gorham, New Hampshire, lassen vermuten, dass zahlreiche glaziale Vorstöße in den nördlichen White Mountains stattfanden. Frühere Forscher waren sich nicht einig, ob diese Vorstöße lokaler oder regionaler Natur waren, doch stimmten sie darin überein, dass sie alle während der Rückzugs-Phase der Spät-Wisconsin-Eisdecke geschahen. Neue stratigraphische und geomorphologische Forschung zeigt dagegen, dass ein dickes und regional ausgedehntes Till diese Stratigraphie überlagert und dass dieses Till durch die letzte vollglaziale Episode abgelagert wurde, welche die Region beeinflusste, die Spät-Wisconsin-Vereisung. Die stratigraphische Position dieses Tills zeigt also, dass das darunterliegende Till und die glazialen Seensedimente aus der Zeit vor dem SpätWisconsin stammen und viel älter als ursprünglich angenommen sind. Dieser Wechsel in der Altersbestimmung für einen Teil der Peabody-Tal-Stratigraphie stützt die Ausdehnung der Illinoian-Spät-WisconsinStratigraphie "mit zwei Tills" von Zentral- und Süd-Neu-England bis in das Gebiet im Norden des Hochlands der White Mountains.

Manuscrit reçu le 30 avril 1998 ; manuscrit révisé accepté le 8 décembre 1998
* E-mail address: bfnar@cyberportal.net 


\section{INTRODUCTION}

The glaciolacustrine deposits in the lower Peabody River Valley consist of two tills and a diamict interbedded with two lacustrine units (Figs. 1 and 2). These deposits suggest that multiple glacial advances occurred in the northern White Mountain region, but no ages have been established for any of these deposits because organic material for dating is yet to be found. Previous workers (Crosby, 1934; Goldthwait, 1938; Lougee, 1940; Flint, 1953; Goldthwait, 1971; Gerath, 1978; Bradley, 1981; Gerath and Fowler, 1982; Thompson and Fowler, 1989; Haselton and Fowler, 1991) have assumed all these deposits were emplaced during the recessional phase of the Late Wisconsinan ice sheet because no till unit of regional significance was previously recognized at the top of the stratigraphic section.

However, recent stratigraphic and geomorphic reconnaissance in the Peabody Valley shows the basis of this assumption is erroneous. The author's work has detected a thick and areally extensive surface till stratigraphically overlying the glaciolacustrine deposits in the valley. The position and morphology of this till show it was deposited during the Late Wisconsinan glacial maximum and that the glacial and glaciolacustrine deposits below it are of pre-Late Wisconsinan rather than Late Wisconsinan age as previously assumed.

These changes in age assignment are important for two reasons. First, the lower Peabody Valley becomes the second known locality north of the White Mountain Highlands with glaciolacustrine deposits of pre-Late Wisconsinan age; the first being located at Stark, New Hampshire, where two tills are separated by a glaciolacustrine unit along Nash Stream (Koteff and Pessl, 1985). Second, this locality supports Koteff and Pessl's (1985) extension of the pre-Late Wisconsinan and Late Wisconsinan "two-till" stratigraphy of southern and central New England into northern New Hampshire.

\section{PREVIOUS INVESTIGATIONS}

The distinctive deposits of the lower Peabody River valley have been the subject of investigation, speculation, and controversy for more than 130 years, although during that time, their stratigraphy has never been studied at more than a reconnaissance level by any investigator. Access to these exposures is poor because of rugged terrain, dense vegetation, slippery footing, and in some cases long distances from roads. In addition, the excavation and long-term maintenance of cleaned study sections in the poorly-consolidated and easily eroded sediments is extremely difficult. Here as in most of the region, stratigraphic investigations are undertaken mainly when old exposures are refreshed or new ones created by flooding in the flashy mountain watersheds (e.g. Koteff and Pessl, 1985).

The first general description of these deposits was published by Packard (1867). He described them as "... fine examples of true glacial moraines... presenting vertical cliffs from fifty to one hundred feet high of clay, sand, and gravel... mixed in confusion..." (except) "... near the top of the deposit

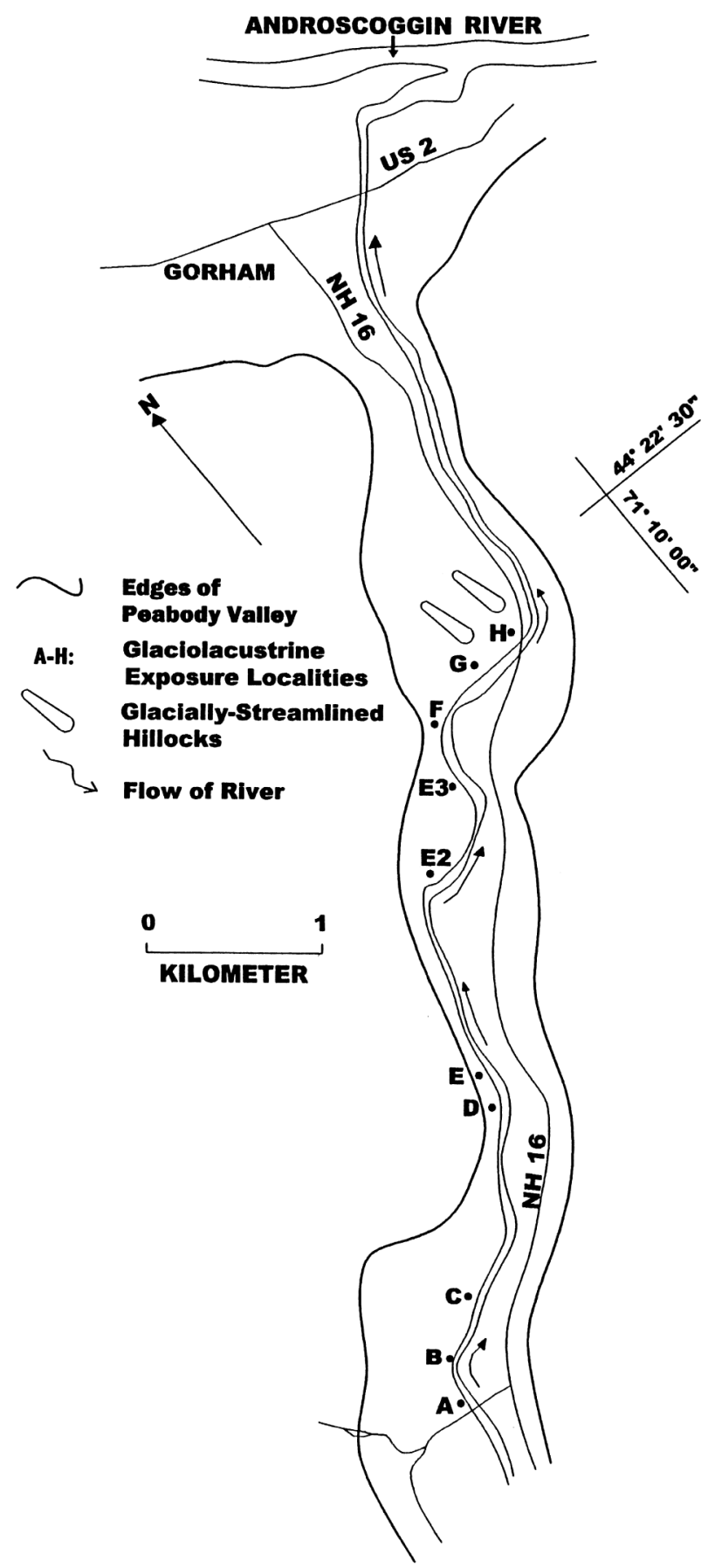

FIGURE 1. Locations of glaciolacustrine sediment exposures and glacially-streamlined topography in the lower Peabody River Valley of northern New Hampshire. Map shows portions of the Berlin and Carter Dome 7.5 Minute U.S.G.S. Quadrangles.

Carte de localisation des sédiments glaciolacustres mis à nu et des buttes glaciaires de la vallée inférieure de la Peabody River dans la partie nord du New Hampshire. Tirée des cartes topographiques de Berlin et de Carter Dome du U.S.G.S.

(where) there is a rude stratification..." Thereafter, Vose (1868), Agassiz (1870), and Hitchcock (1878) cited the deposits in general discussions of the regional glacial geology, but did not report results from any additional field work 


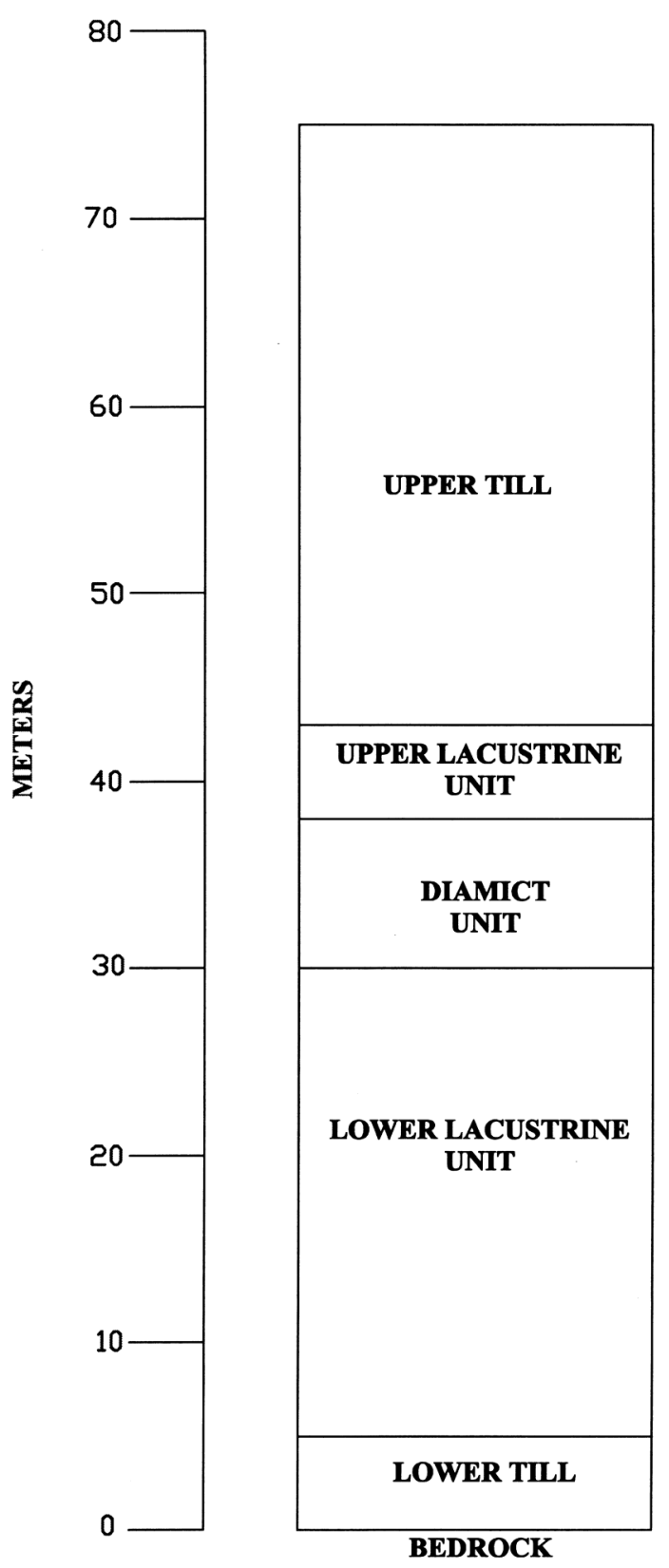

FIGURE 2. Composite glaciolacustrine stratigraphy of the lower Peabody River (Gorham, New Hampshire).

Stratigraphie glaciolacustre de la vallée inférieure de la Peabody River (Gorham, New Hampshire).

on the exposures. Purington and Goldthwait (1932) reported some additional field work in connection with a construction materials survey, but neither they nor any earlier worker addressed the genesis and relative age of the units comprising the deposits.

The first such discussion occurred when Crosby (1934) cited the presence of the deposits in the valley as evidence of a late-stage, Late Wisconsinan regional readvance. Goldthwait (1938) rejected such a regional readvance on geomorphological grounds, but later Lougee (1940) and Flint
(1953) reaffirmed it, citing both the general stratigraphy of the deposits and their own interpretation of the regional geomorphic evidence. None of these workers, however, contested Crosby's suggestion of a Late Wisconsinan age for the deposits.

Gosselin (1971) published a site-specific description of the deposits in the exposure at Locality F (Fig. 1), and Goldthwait (1971) completed fabric analyses and stone counts at the same locality on the two lower, non-lacustrine units he believed were tills deposited by separate glaciations. Both these workers commented on possible modes of deposition for the units in the exposure, but neither addressed their possible or relative age nor the possible involvement of local or regional readvance in their emplacement.

Gerath (1978) used evidence from detailed geomorphic work in the area to suggest for the first time that a local rather than regional readvance of Late Wisconsinan ice occurred in the Androscoggin Valley. He proposed this local readvance deposited a morainal dam, including the sediments described here, into the mouth of the Peabody Valley (vicinity of $\mathrm{G}$ and $\mathrm{H}$, Fig. 1), but he did not propose a depositional sequence to account for the emplacement of the specific stratigraphic units.

Bradley (1981) disagreed following his own reconnaissance of the deposits, and suggested they were not part of such a morainal dam. He proposed they were instead sediments deposited by meltwater from a late-glacial ice tongue related to an oscillating regional readvance that periodically advanced and retreated in the Peabody Valley. Bradley proposed that the tills were deposited during advances of this ice tongue and the lacustrine deposits during its retreats, when proglacial lakes formed between the ice margin and the reverse slope of the valley. He cited most of the previous geomorphologic arguments supporting regional readvance (Crosby, 1934; Lougee, 1941; Flint, 1953) in concluding this late-stage activity was not the result of a local readvance. Gerath and Fowler (1982) disputed the geomorphological basis of this proposal, but not the possibility of late-glacial southward ice flow up the Peabody Valley.

Work by Thompson (1983) and Thompson and Fowler $(1986,1989)$ to the east along the Maine-New Hampshire border confirmed the existence of the Androscoggin Moraine (Stone, 1880; 1899) and conclusively demonstrated the presence of a locally active readvance in the Androscoggin Valley during the recession of the Late Wisconsinan ice sheet. Haselton and Fowler (1991) built on this, suggesting that the topography at Gorham diverted a subsidiary branch of this Androscoggin ice tongue southward into the Peabody Valley, creating the proglacial lake proposed by Bradley (1981). From this and new reconnaissance of scattered and partial exposures of the glaciolacustrine deposits along the river (A-H, Fig. 1), they proposed the first composite stratigraphy attempted for the valley. This stratigraphy relied on a sequence of short and diverse depositional episodes related to oscillations in the 
position of this local ice tongue to account for the emplacement of all the stratigraphic units during the recessional phase of the Late Wisconsinan ice sheet.

\section{RECENT STRATIGRAPHIC AND GEOMORPHIC FINDINGS}

Figure 2 presents a revised composite stratigraphy for the lower Peabody Valley that has resulted from this author's work. This composite is based on observations of partial sections at a number of locations in the valley (Fig. 1), because no single exposure includes all the units presented in Figure 2. Attempts to spatially correlate these units by fence diagramming failed because the considerable relief and irregular gradient in the valley creates significant lateral discontinuity between the exposures. However, the relationships observed between the principal units at nearby exposures in the lower part of the valley suggest this stratigraphic arrangement is correct. A general description of each of the units is presented below.

\section{LOWER TILL UNIT}

Recent field work has located this unit only at Locality $E$ (Fig. 1) where a section about one meter thick was observed in the bed of the Peabody River (October, 1997). Earlier work found sections of this unit up to $5 \mathrm{~m}$ thick elsewhere in the valley (R.P. Goldthwait, pers. comm.), but recent reconnaissance has failed to relocate them, probably because of erosion and slumping along the steep river banks.

The unit consists of gray to olive-gray, very compact, fissile, pebbly to bouldery till with a matrix predominately composed of clayey silt. Most clasts observed are unweathered, weakly to moderately well striated, and sharply faceted, with lithologies reflecting a distinct northwesterly provenance. No mineralization, staining, or deep weathering is present along jointed surfaces in the till or along its sharp contact with the lacustrine unit above.

Except for the absence of deep surface weathering and differences in clast provenance, the character of this till closely resembles that of the lower till unit described by Koteff and Pessl (1985) at the Nash Stream locality. They named their lower till the Nash Stream Till and generally described it as an olive-gray, compact, and silty till with 6-10 m of oxidation present at the top of the unit where it had been subaerially exposed following deposition. Where it had not been subaerially exposed, as in places where it had been immediately covered by lacustrine deposits, no oxidation profile was observed.

\section{LOWER LACUSTRINE UNIT}

This unit is frequently exposed in the lower portions of the valley with its best exposure at Locality $F$. The unit is about $25 \mathrm{~m}$ thick and consists of irregularly alternating 0.3 to $1.0 \mathrm{~m}$ sets of undeformed sandy-silty rythmites and poorly to moderately well-developed silty and clayey varves. Within these sediments are occasionally found blocks up to $0.3 \mathrm{~m}$ in diameter of compact, pebbly to cobbly diamict with a matrix and clast provenance closely resembling the underlying till. Sin- gle dropstones of cobble to boulder size with surrounding conformal bedding are irregularly scattered within the unit, along with lenses up to $15 \mathrm{~cm}$ thick of fine to coarse sand that commonly have graded bedding. The unit appears to be unweathered, with no internal or surficial discoloration along its sharp contacts with the units above and below. Previous reports by Haselton and Fowler (1991) that micro-faulting and other forms of internal deformation were widespread within the unit have not been confirmed by recent work.

\section{DIAMICT UNIT}

This unit is approximately $8 \mathrm{~m}$ thick and consists of the following facies: interstratified, laterally discontinuous and locally deformed, sometimes lensatic deposits of poorlysorted, light gray to olive gray, cobbly, silty till; medium to fine silty gravel; coarse to fine clayey silt; coarse to fine slightlysilty to very silty sand; and scattered laminations of silty clay. The clast sizes in the till facies of the unit generally range from cobbles to boulders and most reflect a distinct northwesterly provenance. The unit appears fresh and unweathered, and no internal or surficial discoloration is observed at its sharp contacts with the units above or below. The general texture of the unit and the provenance of its clasts closely resemble the Lower Till described above.

Previous reports by Haselton and Fowler (1991) that the basal facies of this unit consists of a concentration of winnowed boulders at most exposures in the valley have not been confirmed by this author. Instead, this work shows that such bouldery concentrations appear at many locations and elevations within the unit and are likely the result of the varying types of deposition typically associated with debris flows in this mountainous region (Fowler, 1984; Waitt and Davis, 1988).

\section{UPPER LACUSTRINE UNIT}

This unit is approximately $5 \mathrm{~m}$ thick and consists entirely of extensively deformed, fine silty to coarse sandy rythmites which are locally interbedded with lenses up to $15 \mathrm{~cm}$ thick of massive silty sand or clayey silt. The sandier rythmites sometimes contain graded bedding and poorly-developed cross-stratification showing radically varying orientations because of the extensive internal deformation. The mildest deformation consists of thickening and thinning of individual beds, while the most intense includes micro-folding and faulting of these beds. Occasionally, the axes of these microstructures appear to be imbricated, although previous reports that this imbrication generally dipped to the north (Haselton and Fowler, 1991) have not been confirmed by recent work. The unit appears fresh and unweathered, and no internal or surficial discoloration is observed at its sharp contacts with the units above or below.

\section{UPPER TILL UNIT}

This unit was previously undetected in the lower Peabody Valley. The author's reconnaissance shows it is widespread on the upper and middle slopes of the valley, as well as in areas throughout the Androscoggin Valley to the north and west of Gorham. At several locations it consists of up to $30 \mathrm{~m}$ 
of massive to moderately well-stratified, gray to light olivegray to tan, loose to moderately compact, cobbly to very bouldery glacial till. Its matrix consists predominately of medium to coarse silty sand and fine sandy silt with locally abundant lenses of stratified coarse to medium pebbly sand, medium to fine sand, laminated fine silty sand, massive to locally laminated silt, and minor interbeds of silty clay.

The unit is dominated by very large boulders ranging from 1.0-3.5 $\mathrm{m}$ in diameter. These boulders are distinctly larger than any found in other till or diamict units in the Peabody Valley. Most of the large boulders are faceted and unweathered, while the cobbles in the matrix are faceted and some with finer-grained lithology are striated. The clasts in the matrix that are not faceted are subrounded with smoothed surfaces, and regardless of size, all of the clasts have a distinct northwesterly provenance.

Aside from the prevalence of the very large boulders and their specific provenance, the character of this till closely resembles that of the upper till unit described by Koteff and Pessl (1985) at Nash Stream. They named that till the Stratford Mountain Till and generally described it as a light olivegray to olive, loose to moderately compact, sandy-silty till.

Recent geomorphic reconnaissance of major positiverelief features above the floor of the Peabody Valley, and stratigraphically higher than the glaciolacustrine deposits, shows they are everywhere comprised of the Upper Till unit and are generally streamlined in a northwesterly to southeasterly orientation. Figures 1 and 3 show the streamlined topography of two such ridges with significant relief in the northern part of the valley. These elongated ridges are composed exclusively of the Upper Till and are oriented between $\mathrm{N} 25^{\circ} \mathrm{W}$ and $\mathrm{N} 35^{\circ} \mathrm{W}$. Both ridges have approximately 5-8 $\mathrm{m}$ of relief above the surrounding flatter topography, which is underlain by $9-20 \mathrm{~m}$ of Upper Till. The slope of the lateral surfaces of the ridges ranges from $20^{\circ}$ to $32^{\circ}$, and all surfaces on the ridges are littered with large cobbles and boulders up to $3.5 \mathrm{~m}$ in diameter. All these cobbles and boulders display a distinct northwesterly provenance, and all surficially exposed boulders are sharply faceted, but not striated.

In surficial form, orientation, and composition, these ridges closely match the numerous, strikingly prominent, streamlined and fluted ridges described by Gerath (1978) and Thompson and Fowler (1989) in the region immediately north of the lower Peabody Valley. The fact that all these features are comprised exclusively of the Upper Till and that they are aligned with the direction of ice flow during the last regional glaciation shows the Upper Till was deposited by the Late Wisconsinan ice sheet.

Additional reconnaissance in other parts of the valley (Fig. 1) shows that recessional moraines or other features associated with ice sheet stillstand or readvance, such as those shown to be present in the Androscoggin Valley to the northeast (Stone, 1880, 1899; Thompson and Fowler, 1986, 1989), are absent on the side slopes and floor of the lower Peabody Valley. This observation is true for the valley in all

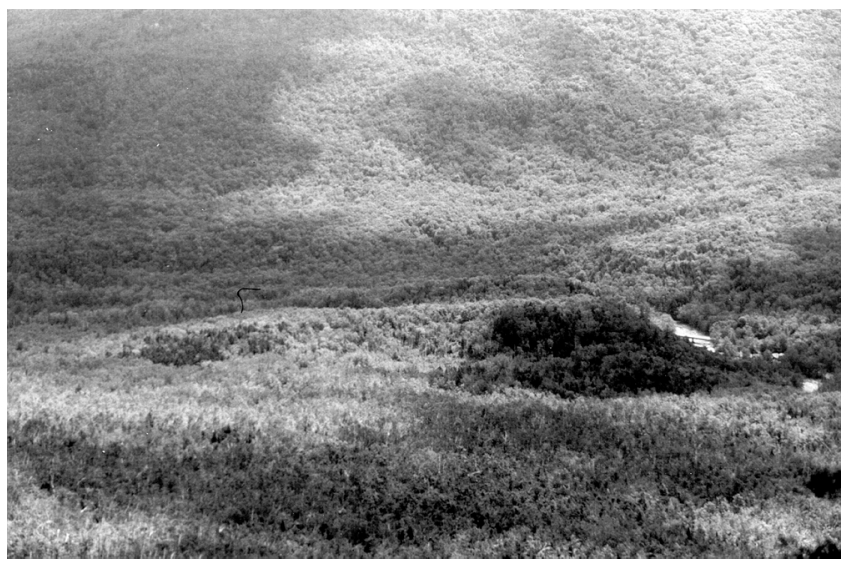

FIGURE 3. Glacially-streamlined, till-based ridges at the northern end of the lower Peabody River Valley, Gorham, New Hampshire. View looks north northeast from the east side of the south summit of Pine Mountain. The northerly hillock is partially hidden by the larger hillock to the south with the tree-less slope at its easterly terminus. Field of view for the photograph is approximately $2 \mathrm{~km}$.

Buttes à base de till profilées par les glaciers dans l'extrême nord de la vallée inférieure de la Peabody River(Gorham, New Hampshire). Vue vers le NNE à partir du côté est du sommet méridional de Pine Mountain. La butte la plus nordique est en partie cachée par la plus grosse butte située plus au sud dont le versant oriental est dénudé. La profondeur de vue est d'environ $2 \mathrm{~km}$.

areas between Gorham and the height of land at Pinkham Notch, about $16 \mathrm{~km}$ to the south (about $5 \mathrm{~km}$ south of the area shown in Fig. 1).

\section{DISCUSSION AND CONCLUSIONS}

The recent results reported here permit several conclusions and the following discussion of glacial and late-glacial activity in the lower Peabody Valley.

First, the Upper Till unit is part of the surface till deposited by the Late Wisconsinan ice sheet and was emplaced during the maximum phase of this glaciation. Given this relative age, the till and glaciolacustrine deposits beneath the Upper Till are of pre-Late Wisconsinan and likely Illinoian age and not younger as previously assumed.

Second, the similarities in stratigraphic position and physical properties of the two tills in the Peabody Valley and those at Nash Stream suggest a probable correlation of the two glaciolacustrine stratigraphies. Figure 4 presents a comparison of the stratigraphy reported by Koteff and Pessl (1985) for the Nash Stream locality and that presented here for the Peabody Valley. It is apparent that, with the exception of the two comparatively thin intermediate units in the Peabody section, the general sequence of depositional episodes at the sites is very similar. Both sections include a lower till, overlain by a lacustrine unit, which is in turn overlain by an upper till.

Koteff and Pessl (1985) initially considered their upper Stratford Mountain Till (Fig. 4) to be Late Wisconsinan and their lower Nash Stream Till to be Early Wisconsinan or possibly older. These authors now think the Nash Stream Till is 


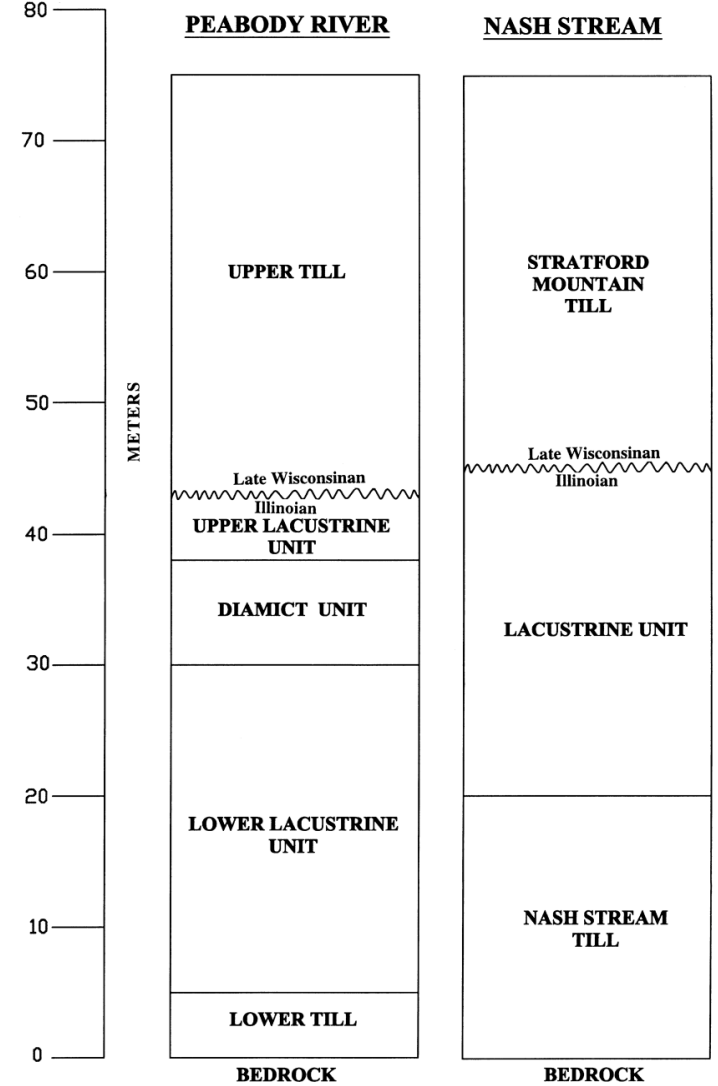

FIGURE 4. Comparative glaciolacustrine stratigraphy in the Peabody River and Nash Stream Valleys, Gorham and Stark, New Hampshire. Nash Stream stratigraphy after Koteff and Pessl (1985).

Stratigraphies glaciolacustres comparées des vallées de la Peabody River et du Nash Stream (Gorham et Stark, New Hampshire). La stratigraphie du Nash Stream est de Koteff et Pessl (1985),

probably Illinoian (Koteff, pers. comm.) for two principal reasons. First, Early and Middle Wisconsinan glaciations are not recognized south of the Canadian border (e.g. Eyles and Westgate, 1987; Oldale and Colman, 1992), and second, a thick weathering profile of up to $10 \mathrm{~m}$ on the Nash Stream Till is very similar in nature and thickness to profiles on probable Illinoian tills in central and southern New England (Koteff, pers. comm.). Given the foregoing, the intervening glaciolacustrine unit is now believed to be the result of a proglacial lake dammed in the valley by the receding Illinioan ice sheet (Koteff, pers. comm.).

In view of this correlation between the stratigraphies, identical age assignments can be applied to equivalent units in the Peabody Valley if the Diamict and the Upper Lacustrine units are recognized to be the results of local and not regional depositional events. Thus, the Upper Till is related to the Late Wisconsinan glacial maximum and the glaciolacustrine, diamict, and till deposits beneath are most likely deposits emplaced during the advance or retreat of earlier Illinoian glaciation. The presence of the Diamict unit within the general lacustrine section in the Peabody Valley can be accounted for by a difference in the late-glacial depositional environments between the Peabody and Nash Stream val- leys. The Nash Stream site lies in a broad valley with gentle gradients and generally low relief along its margins, while that at the Peabody River lies in a narrow valley with moderate to steep gradients and generally high relief. Consequently, the Nash Stream Valley received sedimentation mainly from advancing and retreating ice, while the Peabody Valley received sediments not only from glacial ice but also from fluvial and debris flow processes on its steep side slopes.

Third, the present work suggests the following sequence of depositional events to account for the glaciolacustrine stratigraphy in the valley. Deposition began with the emplacement of the Lower Till by the Illinoian glaciation. As that ice receded from the valley in late Illinoian time, a proglacial lake formed between the receding ice and the reverse slope of the valley and the Lower Lacustrine unit was emplaced in the lake on top of the Lower Till. The absence of a weathering profile at the top of the Lower Till suggests the lake immediately inundated the floor of the valley as the ice was retreating and that the Lower Till was not subaerially exposed here, as it was at least in part at Nash Stream. The coarser sediments in the Lower Lacustrine unit show its deposition in the narrow lake included both substantial amounts of sediment from the receding ice and periodic deposition from processes on the steep slopes bordering the lake that had been earlier covered by the Lower Till.

At one point these slope processes intensified and an extensive debris flow or flows emplaced the Diamict unit into the proglacial lake. The absence of a weathering profile at the top of this unit and the sharp contact with the Upper Lacustrine unit above show it was never subaerially exposed and that deposition into the lake continued immediately after its emplacement and until the Illinoian ice receded north to the vicinity of Gorham (Fig. 1). At that point, a spillway was opened into the Androscoggin Valley and the proglacial lake drained.

After the draining of the glacial lake, the surface of the Upper Lacustrine unit was most likely subaerially exposed. The intense deformation of these sediments shows that the sections visible today were at or very close to the surface of the unit as the Late Wisconsinan ice sheet advanced over it. As that advance began, the part of the unit that had been modified or weathered in-place during the Sangamon Interglacial was probably inundated by another proglacial lake formed between the advancing Late Wisconsinan ice margin and the reverse slope of the valley. The lacustrine deposits related to such a lake, along with this weathered upper portion of the unit were later completely removed by the Late Wisconsinan ice sheet as it moved over the area. This advance heavily deformed the residual portion of the unit beneath, and eventually deposited the Upper Till over the Peabody Valley and the entire region.

Fourth, the author has found no recessional moraines and other surficial features reflecting stillstand or readvance in the lower Peabody Valley. This shows that the retreating Late Wisconsinan ice sheet did not send tongues of locally or regionally readvancing ice up the Peabody Val- 
ley following its recession and that depositional sequence proposals by previous workers relying on the activities of such readvances are incorrect (Gerath, 1978; Bradley, 1981; Gerath and Fowler, 1982; Haselton and Fowler, 1991). Dissection of the Upper Till and the glacial and glaciolacustrine stratigraphy beneath it in the valley, including any Late Wisconsinan proglacial lake sediments that may have been deposited on the Upper Till during the ice's retreat from the valley, began as soon as the ice had retreated to the vicinity of Gorham and the river gained an outlet into the Androscoggin Valley.

Fifth, the absence of weathering at the top of the Diamict unit locates the Illinoian-Late Wisconsinan contact in this stratigraphy between the Upper Lacustrine unit and the Upper Till unit. Thus, the Illinoian units in the stratigraphy include the Lower Till, which resulted from the Illinoian glaciation, and the Lower Lacustrine, Diamict, and Upper Lacustrine units, which resulted from depositional events during the recessional phase of the Illinoian glaciation. The Late Wisconsinan is represented by only the Upper Till which was deposited by the Late Wisconsinan ice sheet, and the local streamlining and fluting of the surface of the Upper Till most likely occurred during the Wisconsinan glacial maximum when the ice was at its thickest over the region.

The possibility that the Illinoian-Late Wisconsinan contact in this stratigraphy lies between the Lower Till and the Lower Lacustrine unit, and that the stratigraphy above this contact is of Late Wisconsinan rather than Illinoian age, can be rejected for the following reason. If the thick Lower Lacustrine unit was deposited in front of advancing Late Wisconsinan ice, its emplacement at that time would have shielded from later erosion (and thus preserved) a preexisting interglacial weathering profile on top of the Lower Till. Conversely, if it was deposited in front of retreating IIlinoian ice, it would have prevented a weathering profile from developing on the Lower Till because the till's surface would have been immediately inundated by the proglacial lake. Since no weathering profile is present on top of the Lower Till, this latter case appears to pertain and the Lower Lacustrine unit and the stratigraphy immediately above cannot be of Late Wisconsinan age.

Finally, the observations and new age assignments resulting from this work make most of this stratigraphy significantly older then previously assumed and show that neither regional nor local readvances occurred in the Peabody Valley during the recessional phase of the Late Wisconsinan glaciation. In addition, the correlation of the Peabody River stratigraphy with that at Nash Stream will be useful in future more systematic studies in this region.

\section{ACKNOWLEDGEMENTS}

The author is grateful to Carl Koteff, Woodrow Thompson, P. Thompson Davis, Pierre Richard, Jeffrey Cloutier, and an anonymous reviewer for their very helpful reviews and suggestions for the improvement of this manuscript. Thanks are also due to Jennifer Stonecipher who drafted the figures, and to Gerrard Courtin and Lorraine Dupuis who assisted with the translation of portions of the original manuscript. And finally, very special thanks are due posthumously to Dr. Richard P. Goldthwait who originally sparked and continued to encourage the author's interest in the stratigraphy in the lower Peabody River Valley.

\section{REFERENCES}

Agassiz, L., 1870. On the former existence of local glaciers in the White Mountains. American Association for the Advancement of Science. Proceedings, 19: 161-167.

Bradley, D.C., 1981. Late Wisconsinan mountain glaciation in the northern Presidential Range, New Hampshire. Arctic and Alpine Research, 13-3: 319-327.

Crosby, I.B., 1934. Extension of the Bethlehem, New Hampshire moraine. Journal of Geology, 42: 411-421.

Eyles, N. and Westgate, J.A., 1987. Restricted regional extent of the Laurentide Ice Sheet in the Great Lakes basins during early Wisconsinan glaciation. Geology, 15: 537-540.

Flint, R.F., 1953. Probable Wisconsinan substages and late-Wisconsinan events in northeastern North America. Geological Society of America Bulletin, 64: 879-920.

Fowler, B.K., 1984. Evidence of a late Wisconsinan cirque glacier in King Ravine, northern Presidential Range, New Hampshire, USA: Alternative interpretations. Arctic and Alpine Research, 16: 431-437.

Gerath, R.F., 1978. Glacial features of the Milan, Berlin, and Shelburne map areas of northern New Hampshire. MS Thesis, McGill University, 129 p.

Gerath, R.F. and Fowler, B.K., 1982. Discussion of "Late Wisconsinan mountain glaciation in the northern Presidential Range, New Hampshire" by Dwight C. Bradley. Arctic and Alpine Research, 14-4: 369-370.

Gerath, R.F., Fowler, B.K. and Haselton, G.M., 1985. The deglaciation of the northern White Mountains of New Hampshire. In H.W. Borns, Jr., P. LaSalle and W.B. Thompson, eds., Late Pleistocene history of northeastern New England and adjacent Quebec. Geological Society of America, Special Paper 197, p. 21-28.

Goldthwait, J.W., 1938. The uncovering of New Hampshire by the last ice sheet. American Journal of Science, $5^{\text {th }}$ Series, 36-215: 345-372.

Goldthwait, T., 1971. Tills in the Peabody River banks near Gorham, New Hampshire. Senior Paper, Dartmouth College, $18 \mathrm{p}$.

Gosselin, G.A., 1971. A Pleistocene legacy. Mt. Washington Observatory News Bulletin, 12(1): 3-13.

Haselton, G.M. and Fowler, B.K., 1991. Stratigraphy in the lower Peabody Valley, Gorham, New Hampshire, U.S.A. Northeastern Geology, 13(1): 11-20.

Hitchcock, C.H., 1878. Glacial drift. The geology of New Hampshire. III: 177-340.

Koteff, C. and Pessl, F., 1985. Till stratigraphy in New Hampshire: correlations with adjacent New England and Quebec. In H.W. Borns, Jr., P. LaSalle and W.B. Thompson, eds., Late Pleistocene history of northeastern New England and adjacent Quebec. Geological Society of America Special Paper 197: 1-12.

Lougee, R.J., 1940. Deglaciation of New England. Journal of Geomorphology, 3: $189-217$.

Oldale, R.N. and Colman, S.M., 1992. On the age of the penultimate full glaciation of New England. Geological Society of America, Spec. Paper, 270: 163-169.

Packard, A.S., 1867. Ice-marks and ancient glaciers in the White Mountains. American, Naturalist, 1: 260-269.

Purrington, W.F. and Goldthwait, J.W., 1932. Inventory of sand and gravel deposits in New Hampshire, Maps and Open File Report. New Hampshire Department of Public Works and Highways.

Stone, G.H., 1880. Note on the Androscoggin glacier. American Naturalist, 14: 299-302. 
1899. The Glacial Gravels of Maine. U.S. Geological SurveyMonograph 34, $499 \mathrm{p}$.

Thompson, W.B., 1983. The Androscoggin Moraine. The Maine Geologist, $9(3): 5$.

Thompson, W.B. and Fowler, B.K., 1986. The Androscoggin Moraine: Evidence of late-glacial ice flow in the White Mountains. Geological Society of America Abstracts with Programs, 18(1): 71.
Thompson, W.B. and Fowler, B.K., 1989. Deglaciation of the upper Androscoggin River valley and northeastern White Mountains, Maine and New Hampshire. Studies in Maine Geology, 6: 71-78.

Vose, G.L., 1868. Traces of ancient glaciers in the White Mountains of New Hampshire. American Naturalist, 2: 281-291.

Waitt, R.B. and Davis, P.T., 1988. No evidence for post-icesheet cirque glaciation in New England. American Journal of Science, 288: 495-533. 